\title{
Diets of plains vizcacha, greater rhea and cattle in Argentina
}

\author{
JAVIER A. PEREIRA, RUBÉN D. QUINTANA, AND SUSANA MONGE
}

Authors are Dissertation Student and Researcher and Laboratory Chief, Laboratorio de Ecología Ambiental y Regional, Departamento de Ciencias Biológicas, FCEyN, Universidad de Buenos Aires. Ciudad Universitaria, Pabellón II, 1428 Buenos Aires, Argentina; and CONICET Technician, Instituto Argentino de Investigaciones de Zonas Aridas (IADIZA), CRICyT, CONICET. Calle Bajada del Cerro S/N, 5500 Mendoza, Argentina. At the time of the research, the senior author was Thallmann Visiting Scholar (UBA) and Research Associate, Dept. of Organismic and Evolutionary Biology, Harvard University, Cambridge, Mass. USA.

\begin{abstract}
Food habits of plains vizcacha (Lagostomus maximus), greater rhea (Rhea americana) and cattle (Bos taurus) in the Paraná River Delta, Argentina, were studied over 2 years using microhistological analysis of faeces. This was the first study of feeding habits of these herbivores grazing in common in a wetland of Argentina. Poaceae was the main diet component throughout the year for all 3 herbivores, with the exception of spring and summer, when greater rhea consumed a higher proportion of Prosopis nigra (Griseb.) pods. Botanical composition of plains vizcacha and cattle diets was generally similar for the same season but different from that of greater rhea. Panicum milioides Nees., Dichondra microcalyx (Hallier) Fabris. and $P$. nigra were the most consumed species for vizcacha, while $P$. nigra, Plantago myosuros Lam., Solanum sp. L., Spilanthes stolonifera (H. et A.) Baker and $D$. microcalyx dominated the greater rhea diet. The species most consumed by cattle were Luziola peruviana Gmel. and $\boldsymbol{P}$. milioides. Similarities between the diets of plains vizcacha and cattle seem to support the ranchers' view that vizcachas compete with domestic herbivores for forage. However, high overlap in food habits would result in competition only if forage is scarce. Greater rhea and cattle have different foraging patterns and hunting of greater rhea is not justified solely on the basis of forage competition with cattle.
\end{abstract}

Key Words: diet composition, herbivory, Lagostomus maximus, Paraná River Delta, Rhea americana

In farming ecosystems, cattle and other domestic species often co-exist with wildlife. Roughly $80 \%$ of Argentina is dedicated to extensive cattle ranching (CONAPA 1991) where cattle interact with a large number of wild species that use the same resources. However, few studies in Argentina have quantified these interac-

Research was funded by the TX-16 and PICT $98 \mathrm{~N}^{\circ} 04503$ grants of the UBACYT and the FONCYT programmes, respectively. The authors wish to thank Mr. I. Schojett for allowing the study to be conducted on his ranch, D. Villareal for his bibliography contribution and N. Madanes, M. Cagnoni, S. Arias, G. Aprile, N. Fracassi, D. Varela and F. Gagliardi for their field support. A special thanks to L. Azcoaga for her invaluable help with the English translation, Dr. O. Solbrig for his support at Harvard University, and the anonymous reviewers for constructive criticism.

Manuscript accepted 14 May 02.

\section{Resumen}

Se estudiaron los hábitos alimenticios de la vizcacha (Lagostomus maximus), el ñandú (Rhea americana) y el ganado vacuno (Bos taurus) durante 2 años en el Delta del Río Paraná, Argentina, utilizando análisis microhistológico de heces. El presente es el primer estudio que focaliza en la comparación de los hábitos alimenticios de estos herbívoros en coexistencia en un área de humedal. Las poáceas fueron el componente principal en la dieta de los 3 herbívoros a lo largo del año, excepto en primavera y verano, cuando los nandúes consumieron una mayor proporción de vainas de Prosopis nigra (Griseb.). La composición botánica de la dieta de la vizcacha y el ganado fue en general similar para una misma estación pero diferente de la del ñandú. Panicum milioides Nees., Dichondra microcalyx (Hallier) Fabris. y $P$. nigra fueron las especies mas consumidas por la vizcacha, mientras que $P$. nigra, Plantago myosuros Lam., Solanum sp. L., Spilanthes stolonifera (H. et A.) Baker y D. microcalyx dominaron en la dieta del ñandú. Las especies mas consumidas por el ganado fueron Luziola peruviana Gmel. y P. milioides. La similitud entre las dietas de la vizcacha y el ganado parecen apoyar la idea de los ganaderos sobre la competencia por el forraje entre estos herbívoros. Sin embargo, un elevado solapamiento dietario no se traduce en competencia a menos que el forraje resulte escaso. Por otra parte, el ñandú y el ganado presentan diferentes patrones de forrajeo y la cacería que sufren estas aves no esta justificada únicamente sobre la base de la competencia por el forraje.

tions (e.g., Bonino et al. 1986, Kufner and Pelliza 1987, Martella et al. 1996, Quintana et al. 1998a, 1998b).

Plains vizcacha (Lagostomus maximus) and greater rhea (Rhea americana) are 2 native species found in these ecosystems. Plains vizcacha are large nocturnal rodents of the Chinchillidae family that dwell in communal burrows ("vizcacheras") of grasslands and semi-arid scrublands from southern Paraguay and Bolivia to central Argentina (Llanos and Crespo 1952, Branch 1993). Greater rhea also live in grasslands and bush country from Brazil and Bolivia to central Argentina. These birds live in polygamous social clusters and are generally associated with farming and cleared fields where native vegetation has been replaced by improved pastures (Martella et al. 1996, Reboreda and Fernández 1997).

The plains vizcacha is often considered to be an agricultural pest, damaging soil and vegetation (Weir 1974) due to its burrow- 
ing and grazing habits and causing losses in yield of crops such as corn, soybean, pastures, and horticultural species (Rendel 1990, Navarro et al. 1997). It is also hunted for its pelt (Rendel 1990, Bruggers and Zaccagnini 1994) and used as a food resource by humans (Mares and Ojeda 1984). Hunting has severely reduced the numbers of plain vizcachas, and it is now extinct in large tracts of the wet Pampa (Redford and Eisenberg 1992). Greater rhea also have been hunted intensively for meat, feathers and skin, and was declared a harmful species due to its negative impact on crops (Bertonatti 1997) and potential competition with cattle for forage (Martella et al. 1996).

There have been few scientific studies on the feeding habits of these wild herbivores despite their widespread continental distribution. Plains vizcacha are selective grazers (Llanos and Crespo 1952) while greater rhea feed on vegetable matter as well as arthropods and small vertebrates (Bruning 1974).

This study focuses, for the first time, on a wetland area of Argentina (the Paraná River Delta Region) and surveys the food habits of plains vizcachas, greater rheas and cattle sharing the same grazing area.

\section{Materials and Methods}

The study area was located on the "Don José" Ranch $\left(1,500\right.$ ha, $33^{\circ} 27^{\prime} \mathrm{S}$, $\left.58^{\circ} 48^{\prime} \mathrm{W}\right), 6 \mathrm{~km}$ north of Ceibas, Department of Gualeguaychú, Entre Ríos province, Argentina. Mean annual rainfall is $978 \mathrm{~mm}$, and temperature averages 17.4 $\mathrm{C}^{\mathrm{o}}$ (Servicio Metereológico Nacional 1972). The study area is situated in one of the 11 wetland landscape units identified for the Paraná River Delta Region. The landscape pattern corresponds to plains with a savanna physiognomy of grasses, patches of xerophitic Prosopis nigra (Griseb.) and Acacia caven (Mol.) Mol. forest, and baldspots with a large percentage of bare soil and sparse cover of Portulaca sp. L. The area is also crisscrossed by small lentic streams covered with floating and rooted aquatic plants (Malvárez 1997).

Unlike its neighboring areas, the study area is free from the periodical floods of the Paraná River. Large areas are waterlogged by rainfall due to the minimum slope of the land (Malvárez 1997) and the type of soils (Pratolongo 2000). During 1998 , coincident with an "El Niño" event, both the waterlogged areas and the duration of the waterlogging were longer than for 1996/97.
Soils are composed of a clayey, sodic horizon close to the surface. These sodic clays hamper water penetration because they swell when wet, creating a layer that is effectively impermeable. Trampling by cattle compounds the problem by compressing and hardening the soil, and eroding thin layers of topsoil (Arias 2000). Extensive cattle ranching ( 0.7 cows per hectare per year), hunting of wildlife species for food and trade, and exploitation of $P$. nigra trees for lumber are the main human activities in this region.

Vizcachas dig their burrows both in the grasslands and the forest patches and their foraging is restricted to the areas surrounding the burrows (Branch and Sosa 1994, Arias 2000). Greater rhea and cattle, on the other hand, graze over extensive areas, including, in the case of cattle, vegetation from the streams. Cattle were always present on the study area and the overall level of forage utilization was moderate.

Fresh faeces of plains vizcachas and cows were collected seasonally for 2 consecutive years, between November 1996 (spring) and August 1998 (winter). Greater rhea fresh faeces were collected only in spring/summer 1997 and fall/winter 1998, when these birds were present on the study area. Collection dates were in the middle of the respective season. All faeces were collected within the single grazing unit that comprised the study area.

Faeces of plains vizcachas were taken from 8 active burrows located on the edge between grassland and forest patches, while faeces of greater rhea and cattle were collected from droppings found both in grassland and forest patches. We verified the vizcachas' burrows were active through direct observation of the animals, or signs of recent activity such as fresh faeces, footprints or diggings (Branch et al. 1994b). Fifty pellets were collected at each vizcacha burrow (a total of 400 pellets per season) to form 8 composite samples (1 sample per burrow with 50 pellets each). This is an adequate number of samples to estimate this rodent's diet (Bontti et al. 1997). For greater rhea and cattle, 32 and 24 samples of faeces of $4 \mathrm{~g}$ were collected, respectively, and formed into 8 composite samples for both herbivores (each composed of 4 and 3 faeces).

The botanical composition of the diets was determined by means of microhistological analysis using the William's technique (1969). Four slides were prepared from each of the composite samples and 100 randomly chosen microscopic fields were observed at $400 \mathrm{x}$ for each slide
(Holechek and Vavra 1981, Holechek et al. 1982). Frequencies of each consumed item were converted to percentages of the total sample weight (Holechek and Gross 1982, Martella et al. 1996).

Composite samples of greater rhea underwent a special procedure; whole or fragmented pods and seeds of $P$. nigra and arthropods were separated from the herbaceous components and each of these 3 components was dried and weighed. Herbaceous components were then analyzed following the technique described above.

The percent of each food item was calculated for each season. Diet correlations and dietary similarity among seasons and among herbivore species were analyzed using two-tailed Spearman's rank correlation coefficients (Zar 1996) and Kulczynski's similarity index (Smith and Shandruk 1979, Henley et al. 2001), respectively. Data were averaged for the 2 years for plains vizcacha and cattle to compare botanical composition of diets among seasons and herbivores.

\section{Results}

While vizcachas and cattle fed exclusively on plant leaves, greater rhea also fed on $P$. nigra pods and consumed some arthropods (Tables 1, 2, and 3). Plains vizcacha fed on a wide variety of plants during all seasons (Table 1). A total of 45 plant species were identified in vizcacha diets over the length of the study. Grasses were the staple diet of this rodent, both in amount consumed and in number of species, $42.7 \%$ of the diet in winter with 20 species to $65.1 \%$ of the diet in spring with 17 species. Panicum milioides Nees. was the most consumed grass, contributing $8.8 \%$ and $16.4 \%$ of the diet in winter and spring, respectively. The item "Other Grasses" was at times similar to P. milioides $(14.8 \%$ vs. $15.1 \%$ in summer) or even higher (13.4\% vs. $8.8 \%$ in winter). Other major items were Dichondra microcalyx (Hallier) Fabris. (20.4\% and $19.3 \%$, fall and winter) and P. nigra (18.7\% and $13.2 \%$ in fall and winter, respectively).

Legumes were the most common component of the greater rhea diet during spring and summer $(25.3 \%$ and $38.9 \%$; Table 2) while grasses were more common in fall and winter ( $35.8 \%$ and $45.3 \%$ ). The high content of legumes was due mainly to the consumption of $P$. nigra pods $(21.2 \%$ and $37.8 \%$, for spring and summer, respectively). Plantago myosuros Lam. $(20.5 \%)$ and Solanaceae, particularly Solanum sp. L. (13.9\%) were also important in the spring diet while Spilanthes 
Table 1. Botanical composition (\%) of plains vizcacha diets in different seasons in the Delta of the Paraná River.

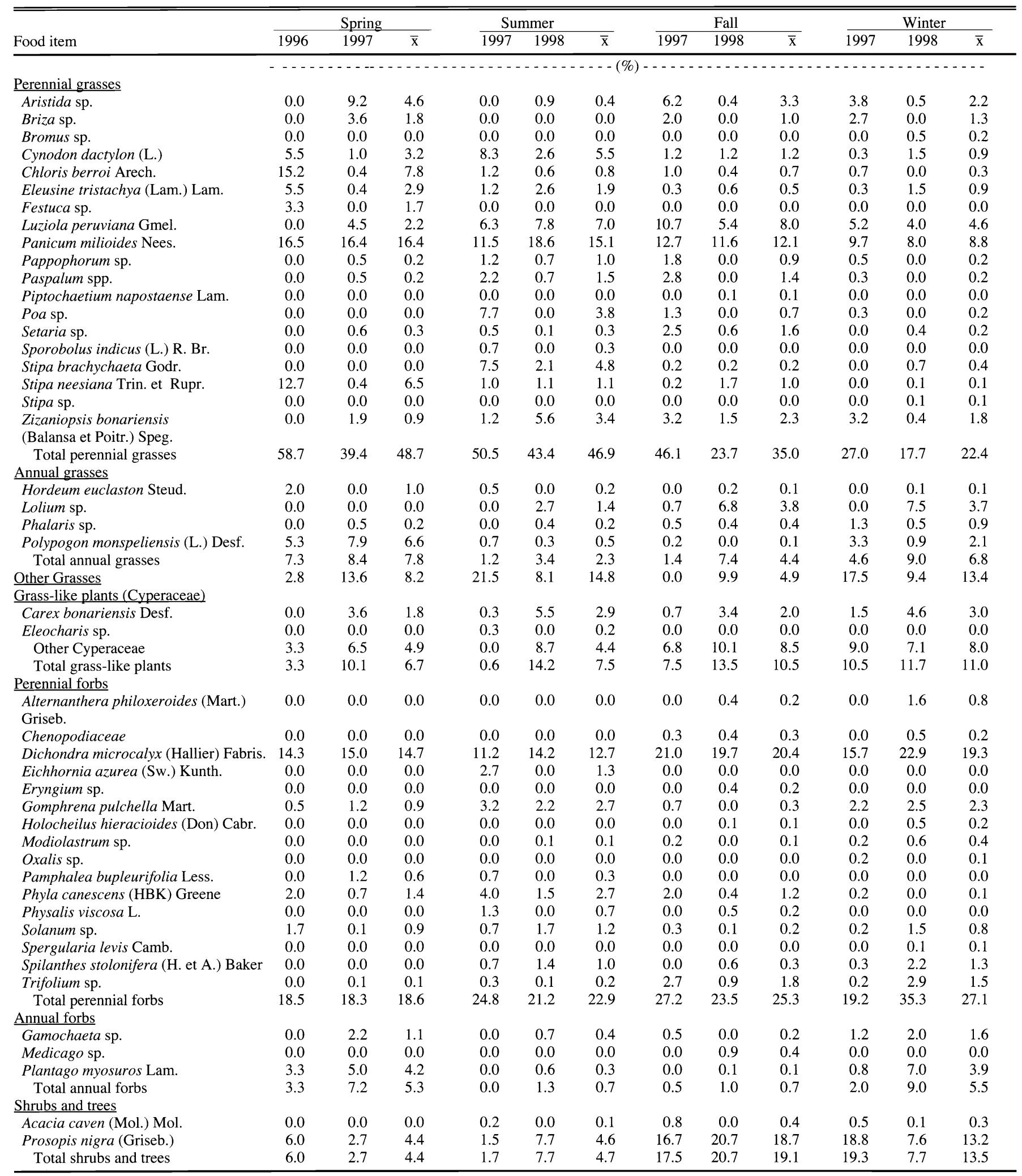

stolonifera (H. et A.) Baker was a major item in summer $(14.9 \%)$ and D. microcalyx was the dominant food item in fall $(34.7 \%)$. In winter, "Other Dicots" sup- plied $18.2 \%$ of the diet. There were traces of arthropod consumption throughout the year, with the highest values in spring $(2.9 \%)$ and winter $(3.0 \%)$.
Grasses were also the dominant group in the cattle diet throughout the year, ranging between $78.3 \%$ in fall and $87.3 \%$ in summer (Table 3). Luziola peruviana Gmel. 
Table 2. Botanical composition (\%) of greater rhea diets in different seasons in the Delta of the Paraná River.

\begin{tabular}{|c|c|c|c|c|}
\hline Food item & $\frac{\text { Spring }}{1997}$ & $\frac{\text { Summer }}{1997}$ & $\frac{\text { Fall }}{1998}$ & $\frac{\text { Winter }}{1998}$ \\
\hline \multicolumn{5}{|l|}{ Perennial grasses } \\
\hline Aristida sp. & 0.0 & 0.0 & 0.5 & 0.0 \\
\hline Bromus sp. & 0.0 & 0.9 & 0.0 & 0.0 \\
\hline Chloris berroi Arech. & 0.0 & 0.5 & 0.2 & 0.2 \\
\hline Luziola peruviana Gmel. & 0.2 & 0.5 & 8.1 & 10.7 \\
\hline Panicum milioides Nees. & 0.6 & 0.0 & 1.9 & 2.9 \\
\hline Pappophorum sp. & 0.0 & 0.2 & 0.0 & 0.0 \\
\hline Setaria sp. & 0.0 & 0.0 & 0.5 & 0.0 \\
\hline $\begin{array}{l}\text { Zizaniopsis bonariensis } \\
\text { (Balansa et Poitr.) Speg. }\end{array}$ & 0.0 & 0.0 & 1.2 & 6.1 \\
\hline Total perennial grasses & 0.8 & 2.1 & 12.4 & 19.9 \\
\hline \multicolumn{5}{|l|}{ Annual grasses } \\
\hline Lolium $\mathrm{sp}$. & 0.0 & 0.0 & 2.1 & 2.9 \\
\hline Phalaris sp. & 0.0 & 0.0 & 0.0 & 0.7 \\
\hline Total annual grasses & 0.0 & 0.0 & 2.1 & 3.6 \\
\hline Other Grasses & 7.2 & 6.0 & 21.5 & 21.8 \\
\hline \multicolumn{5}{|l|}{ Grass-like Plants (Cyperaceae) } \\
\hline Carex bonariensis Desf. & 0.0 & 0.0 & 0.7 & 3.4 \\
\hline Other Cyperaceae & 0.0 & 1.0 & 0.0 & 4.6 \\
\hline Total grass-like plants & 0.0 & 1.0 & 0.7 & 8.0 \\
\hline \multicolumn{5}{|l|}{ Perennial forbs } \\
\hline Chenopodiaceae & 1.0 & 0.9 & 0.2 & 0.0 \\
\hline $\begin{array}{l}\text { Dichondra microcalyx } \\
\text { (Hallier) Fabris. }\end{array}$ & 4.8 & 1.6 & 34.7 & 6.3 \\
\hline Gomphrena pulchella Mart. & 10.8 & 13.0 & 0.0 & 1.0 \\
\hline Holocheilus hieracioides (Don) Cabr. & 0.0 & 0.0 & 0.5 & 0.5 \\
\hline Oxalis sp. & 1.1 & 1.0 & 0.0 & 0.0 \\
\hline Pamphalea bupleurifolia Less. & 0.0 & 0.6 & 0.0 & 0.0 \\
\hline Phyla canescens (HBK) Greene & 9.1 & 13.1 & 4.2 & 1.0 \\
\hline Physalis viscosa $\mathrm{L}$. & 0.0 & 1.1 & 0.0 & 0.0 \\
\hline Solanum sp. & 13.9 & 1.7 & 0.2 & 0.0 \\
\hline Spilanthes stolonifera (H. et A.) Baker & 1.9 & 14.9 & 1.9 & 2.2 \\
\hline Trifolium sp. & 1.0 & 0.0 & 0.0 & 0.0 \\
\hline Total perennial forbs & 43.6 & 47.9 & 41.7 & 11.0 \\
\hline \multicolumn{5}{|l|}{ Annual forbs } \\
\hline$\overline{\text { Medicago sp. }}$ & 0.2 & 0.0 & 5.8 & 3.6 \\
\hline Plantago myosuros Lam. & 20.5 & 0.3 & 6.5 & 8.2 \\
\hline Total annual forbs & 20.7 & 0.3 & 12.3 & 11.8 \\
\hline \multicolumn{5}{|l|}{ Shrubs and trees } \\
\hline Acacia caven (Mol.) Mol. & 0.0 & 0.3 & 0.0 & 0.0 \\
\hline Prosopis nigra (Griseb.) leaves & 3.0 & 0.8 & 0.5 & 2.7 \\
\hline Prosopis nigra (Griseb.) pods & 21.2 & 37.8 & 6.6 & 0.0 \\
\hline Lycium sp. & 0.8 & 0.0 & 0.2 & 0.0 \\
\hline Total shrubs and trees & 25.0 & 38.9 & 7.3 & 2.7 \\
\hline Other Dicots & 0.0 & 1.0 & 1.4 & 18.2 \\
\hline Arthropods & 2.9 & 0.8 & 1.0 & 3.0 \\
\hline
\end{tabular}

and $P$. milioides were commonly eaten (the former between $13.8 \%$ in winter and $25.0 \%$ in summer, and the latter ranging from $9.3 \%$ in winter and $20.0 \%$ in spring) with Zizaniopsis bonariensis (Balansa et Poitr.) Speg. somewhat lower (5.8\% in spring and $9.8 \%$ both in winter and summer). The item "Other Grasses" averaged about $15 \%$ over all seasons. Luziola peruviana and $P$. milioides together with "Other Grasses", constituted 60\%, 63\%, and $58 \%$ of the spring, summer and winter diets, respectively.

Within seasons, vizcacha and cattle diets differed in botanical composition between years (Table 4). Summer and winter diets of the vizcacha were significantly correlated between years but the correlation values were low. Similarity index values showed the same trend, except for fall, when similarity was highest (Table 4).

Plains vizcacha and cattle diets were similar among the different seasons, something that matches the rather high values of the similarity index (Table 5). The diet of greater rhea differed among most seasons, being similar only between spring and summer and between fall and winter. Both comparisons also showed the highest similarity values between diets (Table 5).

Botanical composition of the diets of plains vizcacha and cattle was similar within season and the similarity index values oscillated between 50.5 and 57.9 (Table 6). Inversely, plains vizcacha and greater rhea segregated their grazing resources, without significant associations between diets, except in winter, which again had the highest similarity index value (Table 6). Cattle and greater rhea diets differed most with significant negative correlations; also, the observed similarity index's values showed low values, especially in spring and summer (Table 6).

\section{Discussion}

Grasses were the main forage for plains vizcacha and cattle in all seasons. For greater rhea, grasses were the most important diet component when $P$. nigra pods were lacking. The importance of grasses in the plains vizcacha diet has also been reported by other authors (Giulietti and Jackson 1986, Kufner et al. 1992, Jofré 1994, Branch et al. 1994a, Navarro et al. 1997). Although plains vizcacha grazed on a large variety of plant species, only a few food items composed the bulk of its diet in each season. Thís last fact was observed in other grassland habitats (Giulietti and Jackson 1986), although we found a greater consumption of dicots compared to that study (23 species versus 3 species). Our results are more similar to those from the semiarid scrub of Central Argentina, where $53 \%$ of the species in the diet were dicots (Branch et al. 1994a). The number of items consumed by vizcachas in the Delta Region was 45, while Giulietti and Jackson (1986) and Branch et al. (1994a) record 20 and 62 items in grassland and scrub, respectively. The lower number of items found in the grassland might be explained by higher availability of more palatable species, a fact that might allow the rodents to fulfill their nutritional needs with fewer species, in agreement with classic foraging theory (Stephens and Krebs 1986).

In agreement with other studies (Martella et al. 1996, Comparatore and Martínez 1997), greater rhea had a high intake of greens throughout the year. $P$. nigra pods were an important food item during certain parts of the year. These highly nutritious pods appear in spring, reach their peak during summer, their availability decreases in fall, and they cannot be found in winter (Pratolongo 2000), which correlates with their abundance in the rhea diet.

Variations in digestibility of the different food items could be taking place in the 
Table 3. Botanical composition (\%) of cattle diets in different seasons in the Delta of the Parana River.

\begin{tabular}{|c|c|c|c|c|c|c|c|c|c|c|c|c|}
\hline \multirow[b]{2}{*}{ Food item } & \multicolumn{3}{|c|}{ Spring } & \multicolumn{3}{|c|}{ Summer } & \multicolumn{3}{|c|}{ Fall } & \multicolumn{3}{|c|}{ Winter } \\
\hline & 1996 & 1997 & $\overline{\mathrm{x}}$ & 1997 & 1998 & $\overline{\mathrm{x}}$ & 1997 & 1998 & $\overline{\mathrm{x}}$ & 1997 & 1998 & $\bar{x}$ \\
\hline \multicolumn{13}{|l|}{ Perennial grasses } \\
\hline Aristida $\mathrm{sp}$. & 0.0 & 10.5 & 5.3 & 5.0 & 0.0 & 2.5 & 3.5 & 0.0 & 1.8 & 8.0 & 0.0 & 4.0 \\
\hline Briza sp. & 0.0 & 5.5 & 2.7 & 0.0 & 0.0 & 0.0 & 2.0 & 0.0 & 1.0 & 12.0 & 0.0 & 6.0 \\
\hline Cynodon dactylon (L.) & 3.5 & 0.0 & 1.8 & 0.5 & 0.0 & 0.3 & 3.0 & 4.0 & 3.5 & 0.0 & 0.0 & 0.0 \\
\hline Chloris berroi Arech. & 4.0 & 0.0 & 2.0 & 5.5 & 1.0 & 3.3 & 4.0 & 0.0 & 2.0 & 0.0 & 0.0 & 0.0 \\
\hline Eleusine tristachya (Lam.) Lam. & 0.0 & 0.0 & 0.0 & 4.0 & 2.5 & 3.3 & 0.0 & 1.5 & 0.8 & 0.0 & 0.0 & 0.0 \\
\hline Festuca sp. & 5.0 & 0.0 & 2.5 & 0.0 & 0.0 & 0.0 & 0.0 & 0.0 & 0.0 & 0.0 & 0.0 & 0.0 \\
\hline Lu-iola peruviana $\mathrm{Gmel}$. & 21.5 & 26.5 & 24.0 & 22.0 & 28.0 & 25.0 & 17.5 & 11.0 & 14.3 & 13.0 & 14.5 & 13.8 \\
\hline Panicum milioides Nees. & 31.0 & 9.0 & 20.0 & 14.0 & 11.5 & 12.8 & 14.0 & 8.5 & 11.3 & 4.0 & 14.5 & 9.3 \\
\hline Pappophorum sp. & 0.0 & 0.0 & 0.0 & 0.0 & 0.0 & 0.0 & 0.0 & 3.5 & 1.8 & 0.0 & 0.0 & 0.0 \\
\hline Paspalum sp. & 0.0 & 0.0 & 0.0 & 0.0 & 0.0 & 0.0 & 0.5 & 0.0 & 0.3 & 0.0 & 0.0 & 0.0 \\
\hline Poa sp. & 0.0 & 0.0 & 0.0 & 1.5 & 0.0 & 0.8 & 0.0 & 0.0 & 0.0 & 3.0 & 0.0 & 1.5 \\
\hline Setaria sp. & 0.0 & 0.0 & 0.0 & 0.0 & 2.5 & 1.3 & 5.5 & 0.0 & 2.8 & 0.0 & 0.0 & 0.0 \\
\hline Stipa brachychaeta Godr. & 0.0 & 0.0 & 0.0 & 1.0 & 0.0 & 0.5 & 0.0 & 0.0 & 0.0 & 0.0 & 0.0 & 0.0 \\
\hline Stipa neesiana Trin. et Rupr. & 4.0 & 0.0 & 2.0 & 0.0 & 3.5 & 1.8 & 2.5 & 9.0 & 5.8 & 0.0 & 0.0 & 0.0 \\
\hline $\begin{array}{l}\text { Zizaniopsis bonariensis } \\
\text { (Balansa et Poitr.) Speg }\end{array}$ & 0.0 & 11.5 & 5.8 & 3.0 & 16.5 & 9.8 & 7.5 & 8.5 & 8.0 & 11.5 & 8.0 & 9.8 \\
\hline Total perennial grasses & 69.0 & 63.0 & 66.1 & 56.5 & 65.5 & 61.4 & 60.0 & 46.0 & 53.4 & 51.5 & 37.0 & 44.4 \\
\hline \multicolumn{13}{|l|}{ Annual grasses } \\
\hline Hordeum euclaston Steud. & 1.0 & 0.0 & 0.5 & 0.0 & 0.0 & 0.0 & 0.0 & 0.0 & 0.0 & 0.0 & 0.0 & 0.0 \\
\hline Lolium $\mathrm{sp}$. & 0.0 & 0.0 & 0.0 & 0.0 & 2.5 & 1.3 & 0.0 & 9.0 & 4.5 & 0.0 & 9.0 & 4.5 \\
\hline Phalaris sp. & 0.0 & 0.0 & 0.0 & 0.0 & 0.0 & 0.0 & 3.0 & 1.5 & 2.3 & 0.0 & 1.0 & 0.5 \\
\hline Polypogon monspeliensis (L.) Desf. & 3.5 & 0.0 & 1.8 & 0.0 & 0.0 & 0.0 & 0.0 & 0.0 & 0.0 & 0.0 & 0.0 & 0.0 \\
\hline Total annual grasses & 4.5 & 0.0 & 2.3 & 0.0 & 2.5 & 1.3 & 3.0 & 10.5 & 6.8 & 0.0 & 10.0 & 5.0 \\
\hline Other Grasses & 6.5 & 25.0 & 15.8 & 35.5 & 14.5 & 25.0 & 16.0 & 21.0 & 18.5 & 37.5 & 31.5 & 34.5 \\
\hline \multicolumn{13}{|l|}{ Grass-like Plants (Cyperaceae) } \\
\hline Carex bonariensis Desf. & 0.0 & 6.0 & 3.0 & 0.0 & 12.5 & 6.3 & 0.0 & 7.5 & 3.8 & 1.0 & 5.5 & 3.3 \\
\hline Other Cyperaceae & 0.5 & 2.5 & 1.5 & 0.0 & 0.0 & 0.0 & 3.0 & 8.5 & 5.8 & 0.0 & 4.0 & 2.0 \\
\hline Total grass-like plant & 0.5 & 8.5 & 4.5 & 0.0 & 12.5 & 6.3 & 3.0 & 16.0 & 9.6 & 1.0 & 9.5 & 5.3 \\
\hline \multicolumn{13}{|l|}{ Perennial forbs } \\
\hline $\begin{array}{l}\text { Alternanthera philoxeroides (Mart.) } \\
\text { Griseb. }\end{array}$ & 0.5 & 0.0 & 0.3 & 0.0 & 0.0 & 0.0 & 0.0 & 0.0 & 0.0 & 0.0 & 0.0 & 0.0 \\
\hline Chenopodiaceae & 0.0 & 0.0 & 0.0 & 0.0 & 0.0 & 0.0 & 1.0 & 0.0 & 0.5 & 0.0 & 1.0 & 0.5 \\
\hline Dichondra microcalyx (Hallier) Fabris. & 7.0 & 1.5 & 4.3 & 1.0 & 0.0 & 0.5 & 4.0 & 0.0 & 2.0 & 2.5 & 5.0 & 3.8 \\
\hline Gomphrena sp. & 0.0 & 0.0 & 0.0 & 1.0 & 0.0 & 0.5 & 0.0 & 0.0 & 0.0 & 0.0 & 0.0 & 0.0 \\
\hline Phyla canescens (HBK) Greene & 0.5 & 0.0 & 0.3 & 2.0 & 0.0 & 1.0 & 0.0 & 0.0 & 0.0 & 0.0 & 0.0 & 0.0 \\
\hline Solanum sp. & 0.0 & 0.0 & 0.0 & 1.0 & 0.0 & 0.5 & 0.0 & 0.0 & 0.0 & 0.0 & 0.0 & 0.0 \\
\hline Spergularia levis Camb. & 0.0 & 0.0 & 0.0 & 0.0 & 0.0 & 0.0 & 1.0 & 0.0 & 0.5 & 0.0 & 0.0 & 0.0 \\
\hline Spilanthes stolonifera (H. et A.) Baker & 0.5 & 0.0 & 0.3 & 0.0 & 0.0 & 0.0 & 0.0 & 0.0 & 0.0 & 0.0 & 2.0 & 1.0 \\
\hline Trifolium sp. & 0.0 & 0.0 & 0.0 & 0.5 & 0.0 & 0.3 & 5.5 & 0.0 & 2.8 & 1.0 & 0.0 & 0.5 \\
\hline Total perennial forbs & 8.5 & 1.5 & 5.2 & 5.5 & 0.0 & 2.8 & 11.5 & 0.0 & 5.8 & 3.5 & 8.0 & 5.8 \\
\hline \multicolumn{13}{|l|}{ Annual forbs } \\
\hline$\overline{\text { Gamochaeta } \mathrm{sp} .}$ & 0.0 & 0.5 & 0.3 & 0.0 & 0.0 & 0.0 & 0.0 & 0.0 & 0.0 & 0.0 & 0.0 & 0.0 \\
\hline Plantago myosuros Lam. & 0.5 & 0.0 & 0.3 & 2.5 & 0.0 & 1.3 & 0.0 & 0.0 & 0.0 & 0.5 & 0.0 & 0.3 \\
\hline Total annual forbs & 0.5 & 0.5 & 0.6 & 2.5 & 0.0 & 1.3 & 0.0 & 0.0 & 0.0 & 0.5 & 0.0 & 0.3 \\
\hline \multicolumn{13}{|l|}{ Shrubs and trees } \\
\hline Prosopis nigra (Griseb.) & 10.5 & 1.5 & 6.0 & 0.0 & 5.0 & 2.5 & 6.5 & 6.5 & 6.5 & 2.5 & 4.0 & 3.3 \\
\hline Other Dicots & 0.0 & 0.0 & 0.0 & 0.0 & 0.0 & 0.0 & 0.0 & 0.0 & 0.0 & 3.5 & 0.0 & 1.8 \\
\hline
\end{tabular}

digestive tract. Plant parts in the rhea faeces were hardly degraded. There were only traces of arthropods in the faeces, in spite of their high abundance in the field throughout the year. As with Martella et al. (1996), these traces were highly digested, unlike the plant material. This seems to indicate that this method for diet quantification is unsuitable to analyze the food habits of the greater rhea, because differences in digestibility produce a bias in establishing the true proportion of each item in its diet (Moreby 1988, Rosenberg and Cooper 1990, Martella et al. 1996).

Although the results obtained by com- paring the diet compositions by means of correlations and similarity indices showed on the whole a similar trend, the former were clearer when comparing between years, seasons and species.

Differences observed in botanical composition of the diets of plains vizcacha and cattle between the 2 years could be due to environmental yariability. Observed differences in rainfall might account for variability in both vegetation abundance and grazing area because of the waterlogging, resulting in changes in forage availability. Plains vizcacha avoid waterlogged areas. Waterlogging may also provoke changes in the vegetation which may in turn influence changes in the grazing patterns from one year to the next. While some grasses were eaten less in the wettest year (e.g. Chloris berroi, Stipa neesiana, Polypogon monspeliensis), intake of Cyperaceae grew (See Tables 1 and 3). Despite the yearly changes in the foraging patterns, however, the staple components of the diet kept their high values between the 2 years of the study (e.g. Dichondra microcalyx and Panicum milioides for both vizcachas and cattle and Luziola peruviana for cattle). Thus, these environmental changes corresponded to changes in the grazing patterns 
Table 4. Comparison of the composition of plains vizcacha and cattle diets (Spearman's rank correlation coefficient, $r^{s}$ and Kulczynski's similarity index, $K$ ) between the same season of different years in the Paraná River Delta.

\begin{tabular}{|c|c|c|c|c|c|c|c|c|}
\hline \multirow[b]{2}{*}{ Comparison $^{a}$} & \multicolumn{4}{|c|}{ Plains vizcacha } & \multicolumn{4}{|c|}{ Cattle } \\
\hline & $n^{b}$ & $r_{S}$ & $\mathrm{P}$ & $\mathrm{K}$ & $\mathrm{n}$ & rs & $\mathrm{P}$ & K \\
\hline SP 96 - SP 97 & 28 & 0.10 & 0.61 & 51.7 & 21 & 0.01 & 0.96 & 40.5 \\
\hline SU 97 - SU 98 & 36 & 0.35 & 0.04 & 54.7 & 21 & 0.17 & 0.47 & 54.5 \\
\hline F 97 - F 98 & 39 & 0.30 & 0.07 & 68.5 & 22 & 0.23 & 0.30 & 59.5 \\
\hline W 97 - W 98 & 39 & 0.42 & $<0.01$ & 61.4 & 18 & 0.21 & 0.41 & 62.5 \\
\hline
\end{tabular}

${ }^{\mathrm{a}} \mathrm{SP}=$ Spring; $\mathrm{SU}=$ Summer; $\mathrm{W}=$ Winter; $\mathrm{F}=$ Fall.

$b_{n}=$ Number of food items.

of both herbivores. Something similar was observed for wild and domestic herbivores in central Entre Ríos (Quintana et al. 1998b). This underscores the need to conduct surveys for at least 2 years, as proposed by Hansen and Lucich (1978).

Variations observed in the greater rhea diet throughout the year may be explained by changes in basic nutritional requirements associated with reproductive activities (Bruning 1974, Robbins 1981, Lombardi 1994, Martella et al. 1995, of greater rhea were collected in 1997 , while the fall and winter samples were from 1998, one might think that variation of intake of Prosopis nigra pods between spring/summer and fall/winter could also be due to environmental changes that took place from one year to the next. Yet, intake of these pods corresponded to the availability of Prosopis nigra fruits through the year in this region (Burkart 1976, Pratolongo 2000), supporting our previous argument. europaeus) (Bonino et al. 1986). Increased intake of $P$. nigra leaves by plains vizcacha in fall and summer did not coincide with the results for cattle (except for a slight intake in fall) and this may be due to the wider range of movement of cattle as compared to that of the rodents. Cattle had easy access to areas with more tender, palatable grass, a preferred forage (Hansen and Gold 1977, Vavra et al. 1977, Samuel and Howard 1982). This forage was not as available for vizcachas because their foraging was restricted to the surroundings of their burrows (Branch and Sosa 1994, Arias 2000). Greater rhea diet was more similar to those of the other 2 species in seasons where the intake of Prosopis seeds decreased.

According to Kufner et al. (1992), the larger number of items in the diet of plains vizcachas seems to indicate better adapted grazing habits than those of greater rhea and cattle, when faced with the resources available in their habitat. However, the

Table 5. Comparison of the composition of plains vizcacha, greater rhea and cattle diets (Spearman's rank correlation coefficient, $\mathbf{r}^{\text {s }}$ and Kulczynski's similarity index, K) among seasons in the Paraná River Delta.

\begin{tabular}{|c|c|c|c|c|c|c|c|c|c|c|c|c|}
\hline \multirow[b]{2}{*}{ Comparison $^{a}$} & \multicolumn{4}{|c|}{ Plains vizcacha } & \multicolumn{4}{|c|}{ Cattle } & \multicolumn{4}{|c|}{ Greater rhea } \\
\hline & $\mathrm{n}^{\mathrm{b}}$ & $\mathrm{r}_{\mathrm{s}}$ & $\mathrm{P}$ & $\mathrm{K}$ & $\mathrm{N}$ & $\mathrm{r}_{\mathrm{s}}$ & $\mathrm{P}$ & $\mathrm{K}$ & $\mathrm{n}$ & $\mathrm{r}_{\mathrm{s}}$ & $\mathrm{P}$ & $\mathrm{K}$ \\
\hline$\overline{\mathrm{SP}-\mathrm{SU}}$ & 38 & 0.38 & 0.02 & 63.1 & 29 & 0.48 & $<0.01$ & 71.2 & 24 & 0.58 & $<0.01$ & 56.6 \\
\hline$S P-F$ & 41 & 0.47 & $<0.01$ & 56.9 & 30 & 0.47 & $<0.01$ & 67.9 & 25 & 0.17 & 0.42 & 34.1 \\
\hline SP - W & 41 & 0.51 & $<0.01$ & 61.6 & 27 & 0.48 & 0.01 & 63.3 & 25 & -0.17 & 0.43 & 30.6 \\
\hline$S U-F$ & 43 & 0.61 & $<0.01$ & 62.0 & 28 & 0.50 & $<0.01$ & 68.0 & 30 & 0.07 & 0.72 & 23.3 \\
\hline$S U-W$ & 44 & 0.50 & $<0.01$ & 64.6 & 27 & 0.31 & 0.11 & 69.0 & 28 & -0.17 & 0.36 & 14.9 \\
\hline$F-W$ & 43 & 0.60 & $<0.01$ & 76.6 & 26 & 0.48 & 0.01 & 68.6 & 25 & 0.56 & $<0.01$ & 58.2 \\
\hline
\end{tabular}

${ }^{\mathrm{a}} \mathrm{SP}=$ Spring; $\mathrm{SU}=$ Summer; $\mathrm{W}=$ Winter; $\mathrm{F}=$ Fall

$\mathrm{b}_{\mathrm{n}}=$ Number of food items.

Reboreda and Fernández 1997). Intake of insects, small vertebrates, and seeds satisfy the need of minerals, vitamins, proteins, or specific nutrients in larger or lesser demand according to the season (Robbins 1981, Martella et al. 1996). This intake was higher during spring and summer, the mating season for this species (Reboreda and Fernández 1997). Consequently, the similar diets observed in these seasons and their difference with the fall/winter intake is logical. Since spring and summer faeces
Grazing on common grounds explains the similarity observed in botanical composition of diet observed throughout the year between plains vizcacha and cattle, including a few common dominant species (mainly grasses) and a wide range of less relevant species $(<3 \%)$. Diet similarities between cattle and medium-sized wild herbivores such as the plains vizcacha have also been reported for mara (Dolichotis patagonum) (Kufner and Pelliza 1987) and European hares (Lepus relevance of grasses as a resource shared by this rodent and cattle implies a significant dietary overlap that might be a negative factor for the remaining populations of vizcacha in this area. Plains vizcacha and cattle had similar diets, which supports the ranchers' view that vizcachas compete with domestic herbivores for foraging resources and leads to their being hunted as pests. However, high overlap in the use of resources implies competition only if the resources are scarce (Wiens 1989). Hunting of greater rhea on ranches

Table 6. Comparison of the composition of plains vizcacha (PV), greater rhea (GR) and cattle (CA) diets (Spearman's rank correlation coefficient, $\mathbf{r}^{\mathrm{s}}$ and Kulczynski's similarity index, $K$ ) in different seasons in the Paraná River Delta.

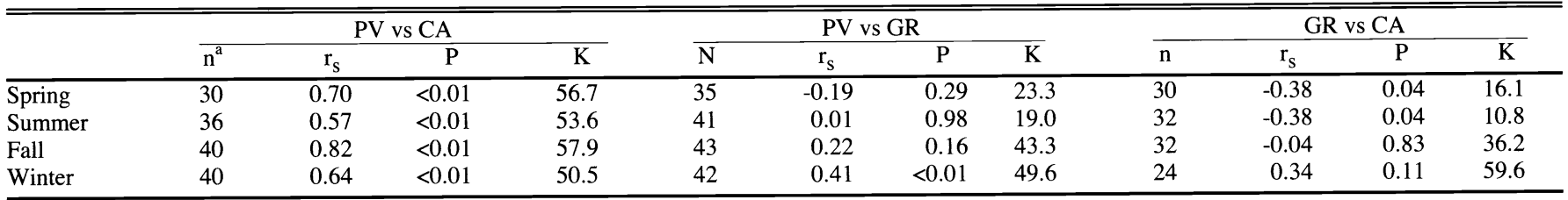

${ }^{\mathrm{a}} \mathrm{n}=$ Number of food items. 
and farms has been justified for the same reason: its perceived competition with cattle for the grazing resources. Our results suggest that greater rhea and cattle have different foraging patterns during the year, with little potential for diet competition.

Both native herbivores may have important ecological roles in this wetland area: greater rhea in forest regeneration, not only dispersing $P$. nigra seeds but also speeding up the germination process as the seeds pass through their digestive tract and improving seed germination rates (Pratolongo 2000). Plains vizcachas help recycle nutrients, increase soil water infiltration through their burrowing activities, which could improve these already degraded soils, and add to the creation of a new habitat type that is used by other wildlife species (Arias 2000).

\section{Literature Cited}

Arias, S. 2000. Effects of the vizcachas (Lagostomus maximus) activity on vegetation and soil in an old marine lagoon of the Delta of the Paraná River Region (In Spanish: Efecto de la actividad de las vizcachas (Lagostomus maximus) sobre la vegetacion y el suelo en una antigua laguna litoral de la region del Delta del Río Paraná.). Graduate Diss., Univ. of Buenos Aires, Buenos Aires, Argentina.

Bertonatti, C. 1997. Conservation strategy for Argentinean birdlife. Readings on Nature and Conservation. Vol. 1 (In Spanish: Estrategia de conservación para las aves de la Argentina. Temas de naturaleza y conservación. Vol. 1.). Asociación Ornitológica del Plata, Buenos Aires, Argentina.

Bonino, N., G. Bonvissuto, A. Pelliza, and R. Somlo. 1986. Food habits of the herbivores in the central zone of "Western Sierras and Mesetas of Patagonia" ecological area (In Spanish: Hábitos alimentarios de los herbívoros en la zona central del área ecológica "Sierras y Mesetas Occidentales de Patagonia"). Revista Argentina de Producción Animal 6:275-287.

Bontti, E., R. Boo, and L. Lindstrom. 1997. Number of samples needed in the vizcachas (Lagostomus maximus) diet estimation (In Spanish: Número de muestras necesario en la estimación de la dieta de vizcachas (Lagostomus maximus)). Abst. XVIII Reunión Argentina de Ecología, Buenos Aires, Argentina.

Branch, L. 1993. Social organization and mating system of the plains vizcacha (Lagostomus maximus). J. Zool. (London) 229:473-491.

Branch, L. and R. Sosa. 1994. Foraging behavior of the plains vizcacha, Lagostomus maximus (Rodentia: Chinchillidae), in semiarid scrub of central Argentina. Vida Silvestre Neotropical 3:96-99.

Branch, L., D. Villareal, A. Pelliza, and R. Sosa. 1994a. Diet selection of the plains viz- cacha (Lagostomus maximus, family Chinchillidae) in relation to resource abundance in semi-arid scrub. Canadian J. Zool. 72:2210-2216

Branch, L., D. Villareal, A. Sosa, M. Pessino, M. Machicote, P. Lerner, P. Borraz, M. Urioste, and J. Hierro. 1994b. Structure of vizcacha colonies and problems associated with estimation of population density from burrow activity (In Spanish: Estructura de las colonias de vizcacha y problemas asociados con la estimación de la densidad poblacional en base a la actividad de las vizcacheras). Mastozoología Neotropical 1:135-142.

Bruggers, R. and M. Zaccagnini. 1994. Vertebrate pest problems related to agricultural production and applied research in Argentina. Vida Silvestre Neotropical 3:71-83.

Bruning, D. 1974. Social structure and reproductive behavior of the greater rhea. Living Bird 13:251-294.

Burkart, A. 1976. A monograph of the genus Prosopis (Leguminosae Subfam. Mimosoideae). Arnold Arboretum 57:219-249.

Comparatore, V. and M. Martínez. 1997. Greater rhea (Rhea americana) diet in an agroecosystem of Villa Gesell Municipality, Buenos Aires Province (In Spanish: Dieta del ñandú (Rhea americana) en un agroecosistema del Partido de Villa Gesell, Provincia de Buenos Aires). Abst. XVIII Reunión Argentina de Ecología, Buenos Aires, Argentina.

CONAPA. 1991. National report to the United Nations Conference about environment and development (In Spanish: Informe Nacional a la Conferencia sobre Ambiente y Desarrollo de las Naciones Unidas). Comisión Nacional de Política Ambiental, Buenos Aires, Argentina.

Giulietti, J. and J. Jackson. 1986. Annual composition of vizcacha (Lagostomus maximus) diet in natural prairies of the San Luis province, Argentina (In Spanish: Composición anual de la dieta de la vizcacha (Lagostomus maximus) en pastizales naturales en la provincia de San Luis, Argentina). Revista Argentina de Producción Animal 6:229-237.

Hansen, R. and I. Gold. 1977. Blacktail prairie dogs, desert cottontails and cattle trophic relations on shortgrass range. J. Range Manage. 30:210-214.

Hansen, R. and G. Lucich. 1978. A field procedure and study design for fecal collections to be used to determine wildlife and livestock food habits. Composition Analysis Laboratory, Colorado State University, Fort Collins, Colo.

Henley, S., D. Smith, and J. Raats. 2001. Evaluation of 3 techniques for determining diet composition. J. Range Manage. 54:582-588.

Holechek, J. and B. Gross. 1982. Evaluation of different calculation procedures for microhistological analysis. J. Range Manage. 35:721-723.

Holechek, J. and M. Vavra. 1981. The effect of slide and frequency observation numbers on the precision of microhistological analy- sis. J. Range Manage. 34:337-338.

Holechek, J., M. Vavra, and R. Pieper. 1982. Botanical composition determination of range herbivore diets: A review. J. Range Manage. 35:309-315.

Jofre, G. 1994. Forage selection by vizcacha (Lagostomus maximus) in a degraded area of the western Chaco of San Luis (In Spanish: Selección de forraje por vizcacha (Lagostomus maximus) en un área degradada del Chaco occidental de San Luis). PhD Thesis, Univ. of San Luis, San Luis, Argentina.

Kufner, M. and A. Pelliza. 1987. Botanic composition of the mara (Dolichotis patagonum) and cattle diets in the monte of Mendoza (In Spanish: Composición botánica de la dieta del mara (Dolichotis patagonum) y del ganado bovino en el monte mendocino). Revista Argentina de Producción Animal 7:255-264.

Kufner, M., M. Chambouleyron, and S. Monge. 1992. Trophic relations in a desert herbivory community in the Monte desert (Argentina) during the dry winter season (In Spanish: Relaciones tróficas de una comunidad de herbívoros del desierto del monte (Argentina) durante la sequía invernal). Iheringia (Porto Alegre), Serie Zoológica 72:113-119.

Llanos, A. and J. Crespo. 1952. The ecology of vizcacha (Lagostomus maximus maximus Blainv) in northeastern Entre Ríos (In Spanish: Ecología de la vizcacha (Lagostomus maximus maximus Blainv) en el nordeste de la provincia de Entre Ríos). Revista de Investigaciones Agrícolas 6:289-378.

Lombardi, C. 1994. Feeding and vigilance in wild greater rheas harems. Bird Behavior 10:29-35.

Malvárez, A. 1997. Plant communities of the Paraná River Delta. Their relation with environmental factors and landscape patterns (In Spanish: Las comunidades vegetales del Delta del Río Paraná. Su Relación con factores ambientales y patrones de paisaje). $\mathrm{PhD}$ Thesis, Univ. of Buenos Aires, Buenos Aires, Argentina.

Mares, M. and R. Ojeda. 1984. Faunal commercialization and conservation in South America. Bioscience 34:580-584.

Martella, M., D. Renison, and J. Navarro. 1995. Vigilance in the greater rhea: effects of vegetation height and group size. J. Field Ornithol. 66:215-220.

Martella, M., J. Navarro, J. Gonnet, and S. Monge. 1996. Diet of greater rheas in an agroecosystem of central Argentina. J. Wildl. Manage. 60:586-592.

Moreby, S. 1988. An aid to the identification of arthropod fragments in the faeces of gamebird chicks (Galliformes). Ibis 130:519526.

Navarro, J., V. Rosati, and E. Fraire. 1997. Effects of vizcachas (Lagostomus maximus) on a soybean crop (In Spanish: Incidencia de vizcachas (Lagostomus maximus) en un cultivo de soja). Mastozoología Neotropical 4:137-144. 
Pratolongo, P. 2000. Structural analysis of Prosopis nigra (Griseb.) Hieron and Acacia caven (Mol.) Mol. populations in south Entre Ríos and comparison of variables related to germination and seedling development (In Spanish: Análsis estructural de poblaciones de Prosopis nigra (Griseb.) Hieron. y Acacia caven (Mol.) Mol. del sur de Entre Ríos y comparación de variables ligadas a la germinación y el desarrollo de las plántulas). Graduate Diss., Univ. of Buenos Aires, Buenos Aires, Argentina.

Quintana, R., S. Monge, and A. Malvárez. 1998a. Feeding patterns of capybara Hydrochaeris hydrochaeris (Rodentia, Hydrochaeridae) and cattle in the non-insular area of the Lower Delta of the Paraná River, Argentina. Mammalia 62:37-52.

Quintana, R., S. Monge, and A. Malvárez. 1998b. Composition and diversity of capybara (Hydrochaeris hydrochaeris) and livestock diets in an agroecosystem of central Entre Ríos, Argentina (In Spanish: Composición y diversidad de las dietas del capibara (Hydrochaeris hydrochaeris) y del ganado doméstico en un agroecosistema del centro de Entre Ríos, Argentina). Ecotrópicos 11:34-44.
Reboreda, J. and G. Fernández. 1997. Sexual, seasonal and group size differences in the allocation of time between vigilance and feeding in the greater rhea, Rhea americana. Ethology 103:198-207.

Redford, K. and J. Eisenberg. 1992. Mammals of the Neotropics. The southern cone. Vol. 2. The University of Chicago Press, Chicago, Ill.

Rendel, C. 1990. Estimation of the vizcacha (Lagostomus maximus B.) damages in the Córdoba province. (In Spanish: Estimación de daños causados por la vizcacha (Lagostomus maximus B.) en la provincia de Córdoba). Revista Argentina de Producción Animal 10:63-79.

Robbins, C. 1981. Estimation of the relative protein cost of reproduction in birds. Condor 83:177-179.

Rosenberg, K. and R. Cooper. 1990. Approaches to avian diet analysis. Studies on Avian Biology 13:80-90.

Samuel, M. and G. Howard. 1982. Botanical composition of summer cattle diets on the Wyoming High Plains. J. Range Manage. 35:305-308.
Servicio Metereológico Nacional. 1972. Climatologic statistics. $4^{\text {th }}$. ed. (In Spanish: Estadística climatológica. 4a. ed). Fuerza Aérea Argentina, Serie B6., Buenos Aires, Argentina.

Smith, A. and L. Shandruk. 1979. Comparison of fecal, rumen and utilization methods for ascertaining pronghorn diets. J. Range Manage. 32:275-279.

Stephens, D. and J. Krebs. 1986. Foraging theory. Princeton University Press, Princeton, N.J.

Vavra, M., R. Rice, R. Hansen, and P. Sims. 1977. Food habits of cattle on shortgrass range in northeastern Colorado. J. Range Manage. 30:261-263.

Weir, B. 1974. The tuco-tuco and plains vizcacha. Symp. Zool. Soc. London 34:113-130.

Wiens, J.A. 1989. The ecology of bird communities, vol. 2. Processes and variations. Cambridge University Press, Cambridge.

Williams, O. 1969. An improved technique for identification of plant fragments in herbivore feces. J. Range Manage. 22:51-52.

Zar, J. 1996. Biostatistical Analysis. Third Edition. Prentice-Hall, N.J. 